\title{
ECONOMIC CONSIDERATIONS FOR THE OUTDOOR RECREATION
}

\author{
Professor Jalil Barkhas \\ Granada University-Spain Faculty Economics and Management Department \\ of Applied Economy \\ Investigating fields: Environmental Economics, Natural Resources, \\ Ecological Economicas, Microeconomics and Macroeconomics
}

Doi: 10.19044/elp.v1no1a1 URL:http://dx.doi.org/10.19044/elp.v1no1a1

\begin{abstract}
The objective of the present paper is analizes important aspects related with the economics of outdoor recreation. Many of these aspects depend on the understanding of the demand for such activity in general and for determined recreational sites. We considered the general issue of the optimal visitation level at a public parks and brought in the issue of congestion cost. Also, given the growth of the population and income, the paper focused on the ration use of public parks from nonfee and fee charge for entry. Then consider the relationship between prices and revenues. Finally, the paper ended syudying the ecotourism, incuding fee options, the possible ecological impacts and the distribution of the generated rent.
\end{abstract}

Keywords: Ourdoor recreational demand, congestion costs, efficient visitation level, rationing use

\section{Introduction}

In this paper, the objective is apply the economic analisis to get an interesting conclusions about the nowadays increasing sector of the outdoor recreational activities. Of course, in wide meaning, the outdoor activities include all leisure's activities which the people hold outside of their house. ${ }^{1}$ Nevertheless, in this paper the focus is those recreational activities where use intensively natural resources, such as forests, lakes, rivers, etc. Now, even there are no clear dividing line between resourse intensive activities and the opposite activties, it is reconizable that activities like picniking in public or national parks are closely linked to the quantity of the natural resources with which the visitors interact, than another activities such as jogging where in

\footnotetext{
${ }^{1}$ One goodreference about the issue is Jensen, Clayne R.
} 
spite of use resources in certain level, the roads in it's case, it does not imply direct demand for natural resources.

The interest of this paper in the outdoor recreational activities arise from the fact that, as could be seen in table. 1 which treat as example the case of US, during the last decades there were evidently a quick growth of such activities in the most developed countries. Table.1 shows that excepting few activities all the others have been increased. Besides, during the last decades, there were a growing private markets dedicated to the outdoor recreasional activities. Such markets cover the hunting, fishing, skiing resorts, whale watching, etc. For this reason, in this paper arise the interest in the managing of the public reservations, the good roles of the public and private initiatives, and the managing problems posing for the specialized firms.

Table.1. Participating in outdoor recreational activities 1982-2000 (numbers in millions of persons)

\begin{tabular}{|c|c|c|c|}
\hline Activities & $\mathbf{1 9 8 2}$ & $\mathbf{2 0 0 0}$ & \% change (1982-2000) \\
\hline Walking & 93.6 & 173.7 & 85 \\
\hline Bird watching & 21.2 & 69 & 225 \\
\hline Sightseeing & 81.3 & 111.5 & 137 \\
\hline Hiking & 24.7 & 69.2 & 180 \\
\hline Swimming (nonpool) & 56.5 & 90.8 & 61 \\
\hline Picniking & 84.8 & 114.4 & 35 \\
\hline Motor boating & 33.6 & 50.6 & 51 \\
\hline Camping (developed área) & 30 & 52.7 & 76 \\
\hline Boating & 49.5 & 76.1 & 54 \\
\hline Camping (primitive area) & 17.7 & 31.9 & 80 \\
\hline Outdoor team sports & 42.4 & 45.4 & 7 \\
\hline Backpacking & 8.8 & 22.4 & 155 \\
\hline Downhill sking & 10.6 & 17.2 & 7 \\
\hline Water skiing & 15.9 & 17 & 79 \\
\hline Snowmobiling & 5.3 & 9.5 & 53 \\
\hline Cross-country skiing & 5.3 & 8.1 & 43 \\
\hline Bicycling & 56.5 & 80.8 & 0 \\
\hline Sailing & 10.6 & 10.6 & 28 \\
\hline Horseback riding & 15.9 & 20.3 & 18 \\
\hline Fishing & 60.1 & 70.9 & 8 \\
\hline Hunting & 21.2 & 22.8 & \\
\hline Note: The table incudes the people aged 16 and & more. \\
\hline Source: USDA Forest Service, National Survey on Recreation and the Environment. 1982-2000. \\
www.srs.fs.usda.gov/trends/nsrr/nsre.html. Accessed 3/12/2007. \\
\hline
\end{tabular}

\section{The demand}

Understand the demand for the outdoor recreational activities is necessary for different perspective. One of them, is to know the demand for 
certain type of outdoor recreational activities among one group of people. For example for one company of Granada which is dedicated to the camping equipment it would be important the information about how the demand for backpacking by the residents of Granada (or all Spain, if it sells by mailorder or online) could be grow during the next years. Of course, studying the future growth of the demand could imply the need to estimate the impact of factors such as the growth of the population or the income, and another possible factors which could also determine how many people would engage in the activity. Then, the company might need to determine the implications of this demand growth for the demand growth of certain products it expect to sell. The perspective is interesting also to the public agencies and private individuals who supply parks and areas necessary for the backpackers to pursue their activities of recreation. ${ }^{2}$

One another perspective is what could be denoted as viewpoint of facilities management. For the in charged of, supposing, a particular park, it is necessary to develop a comprehension of the demand for the park facility which is affected by population, incomes, transportation services and the existence of other competing or complementary areas. A demand curve of the park is shown in figure 1. The horizonal axis has an index of visitor-days, defined as the total number of day-long visits (e.g., two half-day visits make one visitor-day). Note that this may be a significant simplification, since, many parks produce a multiplicity of recreational services, Those include day trips, overnight, longer visits, active recreational visits, sightseeing visits, and others. So, to have manageable study, it is better to boil all these down to one single variable, that is, the choice of visitor days. The vertical axis measure in euros the entrance price to visit the park. Now, even in many cases there are no entrance fee charge, but there are still other costs of visiting the park, specifily, the travel costs of getting there.

In the figure 1, each one of the curves represent different time. Each curve is aggregate demand constructed by the summing all the individual demands curves of the visitors of the park. Now, if we suppose DP represents the past demand, for example of the past decade, and $\mathrm{D}_{\mathrm{A}}$ is the actual demand, $D_{F}$ represent the future expected demand, perhaps one decade in the future. The most important possible factors behind the shift of the demand curve are the growth of the population and the income, decrease of travel costs, build more and better roads, and change in the personal preferences in favor of the outdoor recreation.

\footnotetext{
${ }^{2}$ For an interesting article about the recreational demand preferences, see Daniel WolfWatz, et al. The article explores the linkage between nature-based recreation and preferences of individuals
} 


\section{Figure 1.}

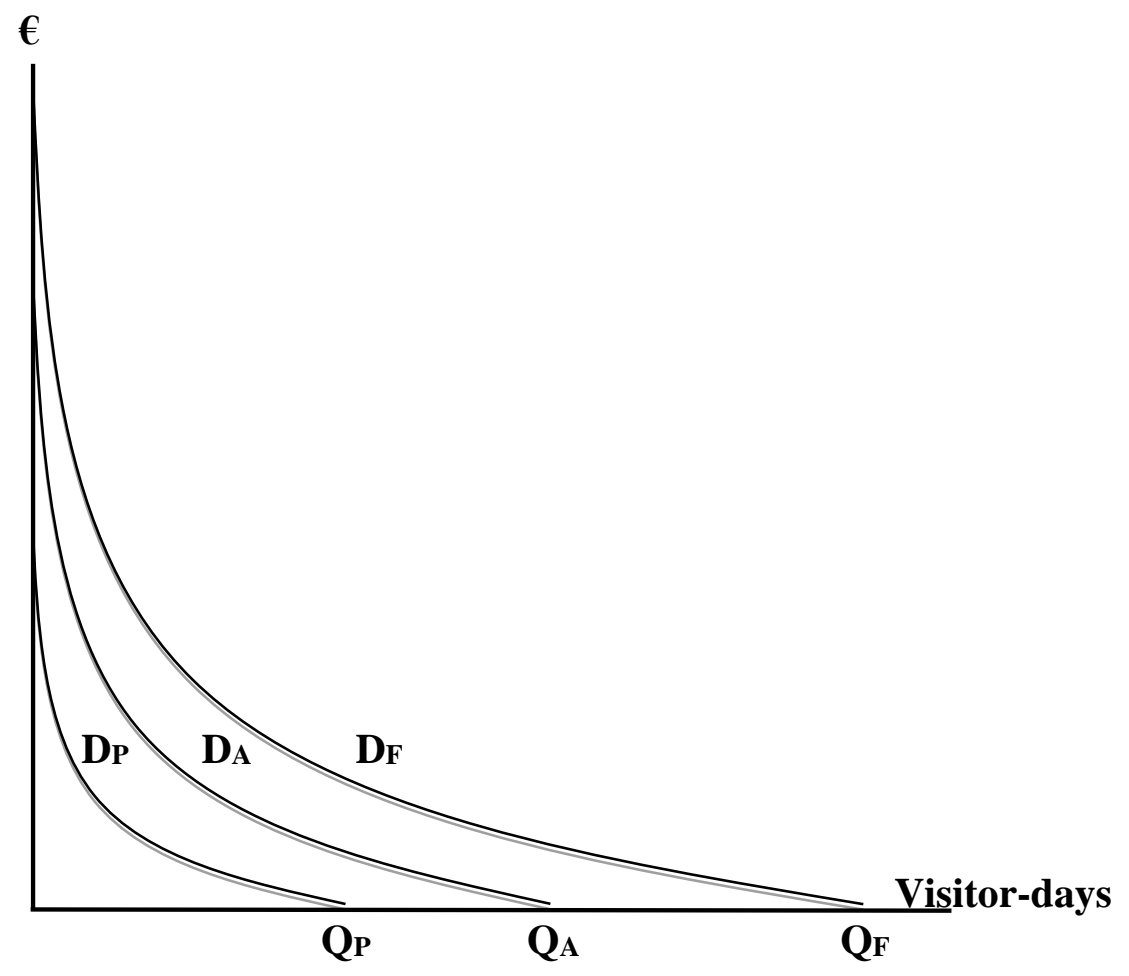

Naturally, in the absence of direct market, it is not difficult suggest the existence of these demand curves, nevertheless, in reality it is not equally easy measuring them or estimate how they have shifted along the time. In stead, the only what have been successfuly developed by the resource economists for assessing the recreational demand functions are techniques of indirect market-price, such as the travel costs as proxies for the normal market prices that are used in market demand analisis. ${ }^{3}$

\section{Efficiency consideration}

In case of areas operating by the private sector, supposedly the area will accepts a visitation level that maximizes the net income. Such level of visitation, to be socially efficient or maximizing the social net benefit, it should be exempted from externalities (environmental or nonenvironmental) arising from the operation, no free riders and that the public goods have standard conditions. ${ }^{4}$ Nontheless, we will focus on the publicly supplied

\footnotetext{
${ }^{3}$ About indirect market approaches, see Barry C. Field; Paul Cameron Mitchell \& Richard T. Carson.

${ }^{4}$ About optimal capacity of resource-based recreation, see Fisher, Anthony C., and John V. Krutilla.
} 
outdoor recreational facilities, since along the history such was the general aspect of their supply, and most of the public facilities have not necessitated significant entrance fee. Following figure 1, if the entrance fee is zero, the past, actual and expected number of visitor-days will be respectively $Q_{P}, Q_{A}$ and $Q_{F}$. Where $Q_{P}$ is the historical number of one decade ago, $Q_{A}$ of the actual year and $\mathrm{Q}_{\mathrm{F}}$ represent the expected visiting level of one decade later. Evidently, the result could not be considered efficiently from the social point of view, since, such visitation rates do not cover the operating and maintaining costs of the park. This fact implies a disconnection between the people who pay for the park and those who use it. So, there will be no excuse to accept that the willingness to pay of the marginal user fits the real marginal cost of accomodating that visitor. Then one more possible cost which will not be covered through a zero entrance fee is the cost of the degradation of certain resources especially when the visitors number is big. The another reason for the ineficiente result, is the presence of the congestion externalities, since, if there is not entance fee, the situation will be of open access, which generally leads to use rate above the social efficient level.

In many of the contingent valuation studies of willingness to pay for backpacking experiences, the possiblility of meeting another backpackers significantly affects the valuations showed by the respondents. ${ }^{5}$ The quantities $Q_{P}, Q_{A}$ and $Q_{F}$ of figure 1 show an increase in the open-access use levels of the park and the congestion externalities tend to increase as the demand curve shifts outward, and finally when the visitors number becomes significantly high, might choke off any further increases in visitation despite increases in population and another factors. This situation could has been occurred in certain natural parks, when during the summer time the visitation rates can be so high that physical capacities are reached. Now, in many other parks where the visitation is bellow the maximum supportable level, question has raised about which is the optimal level and how could be achieved. The answer of such question could be met examinig the model presented by figure 2. In the figure we supposed D is the normal market demand curve of the visits to the public park, $\mathrm{CM}$ is the marginal cost of operating the park and we supposed constant. $\mathrm{D}-\mathrm{C}$ is the demand curve minus the externality of the congestion cost. That is, the congestion cost of each level of visitation, as we supposed, is measured by the vertical distance between the curve $\mathrm{D}$ and the curve $\mathrm{D}-\mathrm{C}$.

Following figure 2, $\mathrm{Q}_{1}$ would be the open access visiting level, $\mathrm{Q}_{0}$ is the social optimal visiting level when there are no congestion costs, since it

\footnotetext{
${ }^{5}$ Regarding the negative relationship between the congestion level and the valuation expressed by the respondents, see Charles J. Cicchetti and V.Kerry Smith.
} 
corresponds to the condition $\mathrm{CM}=\mathrm{D}$. And $\mathrm{Q}^{*}$ is the social optimal level of visitation when there are congestion cost. Now, according to $D$, to achieve $\mathrm{Q}_{0}$, it would be enough fixing the entrance fee equal to $\mathrm{CM}$ and, according to $\mathrm{D}$, to acheive $\mathrm{Q}^{*}$ the entrance fee should be equal to $\mathrm{CM}+\mathrm{C}$. $^{6}$

\section{Figure 2.}

\section{Rationing possibilities}

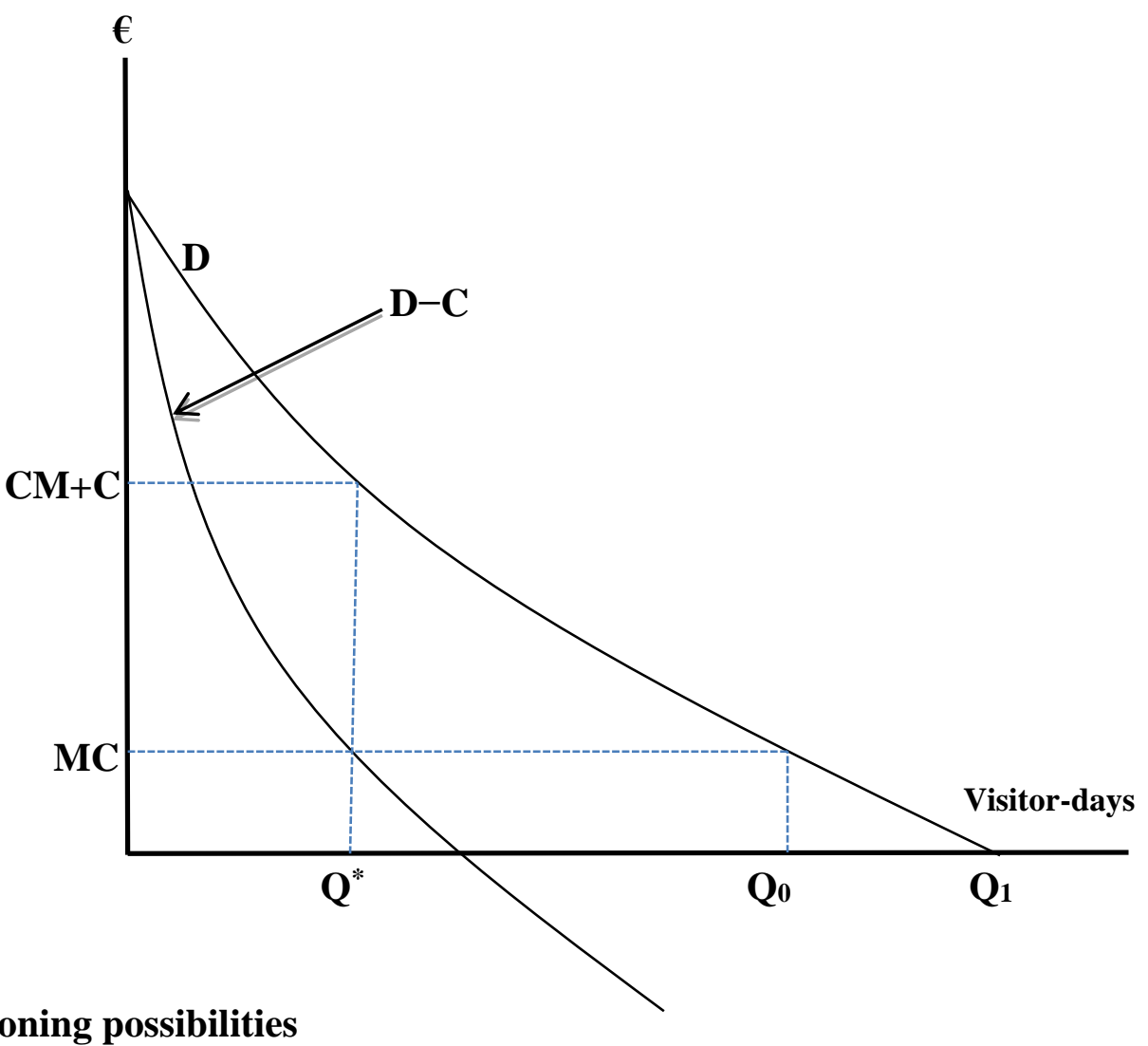

As could be expected, in many recreation areas and public parks the open access causes overuse, congestion and often to the degradation of the natural resources in the área. So, for the managing agency which wish to limit the access till a level consistent with the social efficiency, or exclude all those who only would have continued the visits if the open access had maintained, it would be possible the consideration of several options. One of them is limit the entry to certain categories of people. For example many communities limit the access to the town beach only to the residents of the town. The second option is the first-come, first served. So, determine the desired level of the visitation on the first-arrival basis; when such level of

\footnotetext{
${ }^{6}$ In Hanley, Nick, W., et. al., found good economic treatment of the demand and other aspects of outdoor recreation.
} 
visitation reaches, close the points of entry. The third possible option is charge fee for entry sufficiently that the visitation reduce till $Q^{*}$ of figure 2.

The two first options, which are nonprice based are usually accepted in the name of an equity objective, and normally imply certain amount of wealth distribution, since if the coste of operating the park is not covered by the visitors, it should be attained by other means, for example general tax. This involves that some people will participate in the parks cost and not enjoy their services. Of course, it is posible use the two first options in combination, admiting only the residents of the twon up to certain máximum.

The third option absed in entrance charge to ratinoning the use, historically it has not been commonly used given the consideration of the provision of public parks and reservation as an important part of the civic life and cultural identity, so should not be submited to the market force. Nontheless, this idea is changing for some factors. One, is the need of revenues to cover the costs of park areas. Another factor is the increase of the ecotourism. The third factor is the fast increase of the privately produced outdoor recration. And the last factor, beside the increasing interest in protecting the resources, is that entry price and the revenue generated can permit the expantion of the park system and reservations quantitively and qualitatively. ${ }^{7}$ But, as can be seen for example in the conference paper presented by Aldo Leopold, this is not means that all the opposition to the entrance price has disappeared. These different positions regarding the entrance fee, in practice, led to the application of entrance fees which are too low for social efficiency if congestion is included and possibily too low to protect ecosystems. Eventhough fees create a revenue, the another justification of the entrance fees is to ration the use of scarce asset and to make sure that people who visit the parks are those who value more the experience than the people who do not visit.

\section{Revenue and prices}

In reality a major rationale for the entry fees is to raise revenue, therefore it become importante analize the connection between revenue and the charged fees. Given the demand function, there are certain revenue for each price. Then, given the elasticity of the demand, an increase of the price by one quantity can lead to increase or decrease in the total revenue. The máximum revenue arrives when the demand elasticity is unitary. Above that

\footnotetext{
7 In 1995 Congress of USA enacted the Recreation Fee Demonstration Program, which allowed some federal agenceies, such as the National Park Service, to charge entrance fee. In 2004 this was repassed by the Federal Lands Recreation Enhancement Act (REA), which extended for another 10 years the authorization for entrance fees. The types of entrance fees used, for example, included the entrance fee used by the National Park Service (NPS) and Fish and Wildlife service (FWS).
} 
the demand become elastic, so price increses reduce the revenue and bellow that the demand become inelastic so price decreases also reduce the revenue. According to this fact, the prices which lead to maximize the revenue of the visitation of pubic parks are those corresponding to the point where the demand elasticity is unitary. The figures seen in table. 2 show the results of a research which undertook to investigate the demand for visitation at three national parks in Costa Rica and the results of fixing different entrance prices. $^{8}$

Table.2. Entrance fees of national parks in Costa Rica (all monetary values are in dolars)

\begin{tabular}{|c|c|c|c|}
\hline \multicolumn{4}{|c|}{ Parks } \\
\hline & Volcán irazú & Volcan Poás & $\begin{array}{c}\text { Manuel } \\
\text { Antonio }\end{array}$ \\
\hline Current fee & 12.28 & 9.85 & 9.56 \\
Length average of visit (days) & 1 & 1 & 1.45 \\
Willingness to pay for a visit & 21.75 & 21.60 & 24.90 \\
Fee that visitors think would be & 6.48 & 6.77 & 7.37 \\
acceptable & -1.05 & -2.87 & -0.96 \\
Demand elasticity & 427,307 & 669,940 & 431,371 \\
Current total revenue (1994-1995) & 7.06 & 9.28 & 13.59 \\
Entry fee of maximizing revenue & $1,372,844$ & 675,447 & 518,187 \\
Expected total revenue if revenue & & \\
maximizzing entry fee has been applied & & \\
\hline $\begin{array}{c}\text { One interesting result of the table is that the demand elasticity is not equal for the three } \\
\text { parks, and the current fees in the first and third park are quite different comparing with the }\end{array}$ \\
fees of maximizing revenue. \\
Source: Lisa C. Chase, David R. Lee, William D. Schulze, and Deborah J. Anderson, \\
"Ecotourism Demandand Differential Pricing of National Park Access in Costa Rica", Land \\
Economics, 74 (4), November 1998, pp. 466-482. \\
\hline
\end{tabular}

It should be emphasized that maximizing total revenue is not necessarly recomanded as a good strategy for national parks, forests and another reservations, since, social efficiency requires the maximization of the net benefit, so the prices which maximize the net benefit may not be those which maximize the total revenue. One important reason of such difference, is that the environmental costs should be included when determining social efficiency. They can or can not affect revenues in a consistent way. Thatis, if willingness to pay of the visitors includes the environmental quality of the sites so the environmental degradation affects the demand, then the environmental costs could be totally deducted from the revenue. Nevertheless, visitors may not necessarily be aware of the ecological

\footnotetext{
${ }^{8}$ About national parks of Costa Rica see (http://www.gemlab.ukans.edu/cr).
} 
disruption, therefore willingness to pay may not be an accurate reflection of the environmental status of the park or the reservation.

Another important aspect to take into account when fixing the access fees, is that parks and reservations generally exisit as system, since states have numerous parks and they like to manage in coordinated way, as does the central government with its network of national parks, forests and monoments. In simiar situations may be it is not proper to price each one independently in an attempt to maximize its own total revenue. Prices at the different reservations should be fixed in coordinated way, given the interrelationship among their demands.

\section{Price selection}

It is obvious that the real world is more sophisticated in comparision with the simple models, since not all visitors have equal preferences and consequently their willingness to pay. So, this leads to the question of, for efficiency and/or equity criteria, when is more conveniente the application of equal price and when the different prices. For the answer, first, we should consider the fact that the willingness to pay is higher during the weekend than during the weekdays. Then, different visitors of the same park engage in different actvities, and not all parks are equal en evironmental value or in their closeness to the urban aera. Therefore, to answer the previous question about the preference between equal price and different prices, we can develop some understandable simple principles to help for considering the issue. The first principle is that if the individual demands have different elasticity of demand and the marginal cost, $\mathrm{MC}$, is constant, and there are no congestion, the overall social efficiency requiers simply the achievement of the condition $\mathrm{MC}=$ marginal willingness to pay of each visitor. This is obtiened by setting $\mathrm{P}=\mathrm{MC}$. In this case the social net benefit and/or the agrregate social surplus is maximized. Now, if the MC of serving the different groups is different, achieve the social efficiency requires different prices for the different groups. That is, $\mathrm{P}=\mathrm{MC}$ for each subgroup, so, charging higher price for the group of higher MC. An possible example of this case of different $\mathrm{MC}$ is that rock climbers need higher costs than picnickers given the necessity for closer supervisión, medical attention, etc.

Certain parks have limited capacity, such as campsites or visitation levels where congestion problems start appear. As seen in figure 3, to expose the case we suppose the simple example of one park with constant MC, a number of camping sites indicated as $\mathrm{Q}_{1}$ and two demands, $\mathrm{D}$ for weekday visitors and $D_{1}$ for weekend visitors. $D_{1}$ is bigger than $D$ given the more availablity of time on weekends. In this case efficiency needs two prices. $\mathrm{P}_{0}=\mathrm{MC}$ for $\mathrm{D}$, which leads to an average of weekday visitation of $\mathrm{Q}_{0}$, and $\mathrm{P}_{1}>\mathrm{MC}$ for $\mathrm{D}_{1}$, which leads to $\mathrm{Q}_{0}$ average weekends visitation. For $\mathrm{D}_{1}$ can 
not apply $\mathrm{P}_{0}$, because it leads to the demand of $\mathrm{Q}_{2}$ which is higher than the park capacity. Also, $\mathrm{P}_{1}$ guarantee that the visitors will be those who value most the visit. ${ }^{9}$

Figure 3.

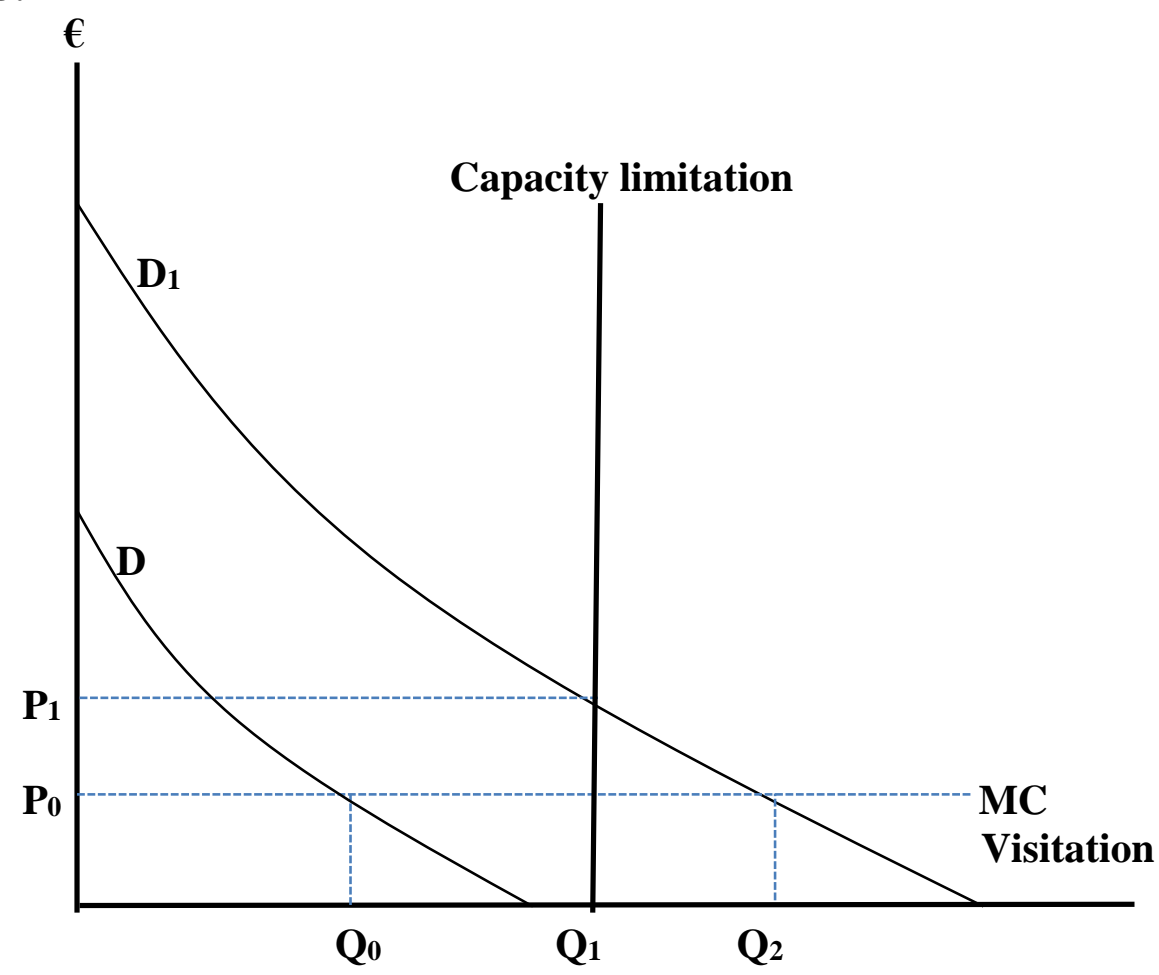

\section{Ecotourisim and natural resources}

Here we refer to the ecotourism which in our modern time is growing increasingly. Such tourism is that where the visits are linked in certain manner to the natural or environmental resources. Now, even the ecotourism includes also national component, but possibily it has more reference to international tourism, especially that from the industrial countries to the developing countries whose endowments are uniquely the natural resources. In certain locals the ecotourism is seen by the people as essential factor for pushing the economic progress, since as stimulus it can lead to increase the value of the natural assets which before were out of the markets and in this way encourge people to put more interest on their conservation. Now, if the tourism increase the value of the natural resources there will be less reasons to deforest them and/or converting them to agricaltural land or pasture.

\footnotetext{
${ }^{9}$ For information about outdoor recreation see (http://www.gorp.com).
} 
Now, regarding the ecotourism, if fees such as that for wildlife tour or park entrance are used to increase the revenue or to protect the resourses from the overuse, then knowing the demand function is also necessary. This need, which faced all along the private firms in the tourism sector and they have supposedly got the necessary knowledege to continue in the market, nevertheless, such obligation is comparatively recent for the public sector, since in the last case, historically the access right has been decided by politicians and who at the same time was the in charged of the pricing. The problema is not simple, because the countries try to reserve many resources which are significantly different in term of types of resources, clientele and objective. $^{10}$

But, besides the positive aspects of converting the resources areas in sources of income through the ecotourism, it is necessary to highlight one possible inconvenient. That is, opening up resources to touristic impact, particularly the resources which are ecologically sensitive, could reduce them quantitatively and/qualitatively in the long run. A great wish to get revenues could lead to excessive visitation comparing with the long run sustainable ecotourism. ${ }^{11}$ Nevertheless, most ecotourism activity is conected with the biological resources, so the question which comes up is about the efficient stock of the resource when used as ecotourism resource. In reality all levels of tourism affects the quantity and/or the quality of the resource. The appropriate quantity and quality of a natural resource submitted to ecotourism will be different from what it would be if there were no tourism. The difference will depends on the trade-off between the value of the biological impact and the economic value of the ecotourism. Adding to that, many ecotourism plans have been undertaken as stimulus to economic progress, which if succeed might become less resource dependent. This should raise the possibility that the efficiente stock of the ecotourism resource is not fixed, at least so far. Since, comparatively, economic progress may call for high use in the short run and less in the long run.

Apart from the previous aspects, it is important have in consideration the institutional elements involved in the management of the ecotourism. One very important is the balance that is necssary to be established between the private and the public sectors. In Spain, as many another countries central or regional governments are directly intervene in the management of the access to national parks, wildlife refuges, etc. In certain cases, such as wildlife in Africa, private companies have established to manage the

\footnotetext{
${ }^{10} \mathrm{~A}$ good exposition of these differences in term of Categories, Objectives and Criteria for Protected Areas can be seen in International Union for the Conservation of Nature (IUCN); J. Mackinnon et al., and Gardner Brown.

${ }^{11}$ About the sustainable ecotourism see Erlet Cater and Gwen Lowman.
} 
ecotourism activities in the market setting. In some cases units of local government function en certain senses as private companies in operating local ecotourism. This is the case of what is known as Campfire (Communal Areas Management Program for Indigenous Resources) in Africa allows local communities, acting collectively, to benefit by selling access to local wildlife resources to the operators of safari.

In any particular case, the preferable institutional arrangment should depends on the characteristics of such case. That is, the resource implicated and the political and economic conditions of the countries. Nontheless, certain general criteria may be possible. When the Ecotourism is based on market principles, the supply should be directed at the demand of the ecotourists. Not all resources that are valuable in cerain biological term are valuable for the tourists. In similar cases, it is important that economically significant resources not be favoured to the detriment of less significant, but ecologically important, resources. When decisions are left to the private sector, this problem is known as negative externality or negative costs. On the contrary, when, decisions are taken in the public sector, that is, by public agencies that are responsible for the ecotourism resources, may be made according to the narrow political interests of those in power, at the expense of other values which could be important for the whole society. From the other side, one more important institutional element is the distribution of the resource rent. In this sense, if the ecotourism is undertaken for the economic progress, it obviously make a difference who recieves the generated rents. If the state recieves them, they are used for objectives that politicians and state planners think to be necessary. If the local individuals recieve them, they may be spent on different products. Besides, in many ecotourism plans the reason is to provide stimulus to conserve the resources in consideration. If this succeeds, the rent should be recieved, at least in large part, by those of the local population who have the power of conserving the specific resource. Therefore, one very effective policy to protect the public ecotourism reservations from the deforestation or poaching by the local people, is possibly giving them one part or another of the generated rent. ${ }^{12}$

\section{Conclusions}

Given the quick growth during the last decades of outdoor recreation together with the corresponding private markets and the increasing concern about the environment and the the depletion of the natural resources, the aim

\footnotetext{
${ }^{12}$ Regarding the information about national parks, visitation, forcasts and impacts on local communities, see National Park Service, Public Use Statistics Office (http://www.aqd.nps.gov./stats). For information about ecotourism see (http://www.ecotourism.org). And about Ecotourism Management, see Lindberg, Kreg.
} 
of this article is to analize the important economic aspects of the outdoor recreation which are resource intensive. The reason of such study is to understand the necessary condition for the efficient management of the outdoor recreation activities.

Now, for the efficient management of the outdoor recreation, it is indispensable the understanding of their demand, since the information about the demand is valuable as much for the private companies of the related market as for the public agencies.

Regarding the efficient level of visitation, such as in the park case, this is not results the same when the resource is managed by private sector instead of public one. So, when the objective of using the resource is satisfying the social efficiency, understand the difference between the private and public management results important for the pricing policies. However, when congestion externality is presented, the socially efficient level requires higher entrance fee and consecuently less quantity of visitors. To limit the access, in addition to the application of a positive entrance fee, there are also nonprice based options available for the managing agencies. Eventhough, recently, the consideration of a new concerns is justfying the more preference of the price based entrance. That is, besides the creation of the revenue, the another justification of the entrance fees is optimizing the use of the scarce asset and to make sure that people who visit the parks are those who appriciate them more than the others.

Even the revenue maximizes when the elasticity of the demand is unitary, however, the entrance fees which maximize the revenue are not necessarly coincide with those which are socially efficient, because, the social efficient fees are only those which maximize the social net benefit. Such distinction is particularly important when the visits involves environmental degradation which, by turn, leads to a difference between the total revenue and the social net benefit.

To fix the recomendable entrance fees when there are different grupos of visitors with a different demands, the application of different prices is prefered above the equal price when the marginal coste is different among the different demandas and also, when certain demandas exceed the maximum visitation capacity of the corresponding area.

When the ecotourism used by the countries to help the economic growth, it could increse the value of corresponding natural resourses and in this way can help to improve their conservation. Now, when the application of fees for ecotourism are aimed to increse the revenue or to improve the conservation of natural resurces, the information about their demand result important. The efficient conservation management, also has to take in consideration various affecting intitutional aspects. 


\section{References:}

Aldo Leopold, Wilderness Recearch Institute, "Societal Responce to Recreational Fees onPublic ands," paper given at a conference on May 2731, 1998, University of Missouri-Columbia (available at www.fs.fed.us/research/rvur/wilderness/recreation_fees.htm).

Cameron Mitchell, Paul \& Carson, Richard T., Using Surveys to Value Public Goods: The Contingent Valuation Methods, Washington, DC, Resources for the Future, 1989.

Charles J. Cicchetti and V.Kerry Smith, "Congestion, Quaity Deterioration and Optimal Use: Wilderness Recreation in the Spanish Peaks Primitive Area," Social Science Research, Vol. 2, 1973, pp. 15-30.

Daniel Wolf-Watz, et al (eds), "Environmentalism and Tourism Preferences: A Study of Outdoor Recreationists in Sweeden," Scandinavian Journal of hospitality and Tourism, 06/2011.

Erlet Cater and Gwen Lowman (eds.), Ecotourism;a Sustainable Option? Wiley, New York, 1994.

Field, Barry C. : Economía Ambiental, McGraw Hill, Madrid, 2003, p. 164.

Fisher, Anthony C., and John V. Krutilla, "Determination of Optimal Capacity of Resource-Based Recreation Facility," Natural Resource Journal, Vol. 12, 1972, pp. 417-444.

Gardner Brown, "Wildlife in Developing Countries," in Parha Dasgupta and Karl-Gören Mäler, The Environment and Emerging Development Issues, Vol. 2. Clarendon Press, Oxford, England, 1997, p.562.

Hanley, Nick, W. Douglas Shaw, and Robert E. Wright (eds.), The new Economics of Outdoor Recreation, Edward Elgar, 2003.

International Union for the Conservation of Nature (IUCN), "Categories, Objectives, and Criteria for Protected Area," in J.A. McNeedly and K. R. Miller (eds.), National Parks, Conservation and Development, Smithsonian Institution Press, Washington, DC, 1984.

J. Mackinnon et al (eds.), managing Protected Area in the Tropics, IUCN, Gland, Switzerland, 1986.

Jensen, Clayne R., and Steven P. Gutherie, Outdoor Recreation in America, 6th ed., Human Kinetics Publishers, Champaign, IL, 2006.

Lindberg, Kreg, and Richard M. Huber, Jr., "Economic Issues in Ecotourism Management," in Kreg Lindberg and Donald E. Hawkins (eds.), Ecotourism, A Guide forPlanners and Managers, Ecotourism Society, North Bennington, VT, 1993, pp. 82-115.

U.S. Department of the Interior, U.S. Department of Agriculture, federal Lands Recreation Enhancement Act: First TriennialReport to Congress Fiscal Year 2006, Washington, DC, May 2006. 